International Journal of Current Microbiology and Applied Sciences

ISSN: 2319-7706 Volume 10 Number 02 (2021)

Journal homepage: http://www.ijcmas.com

\title{
Influence of Different Seed Treatments on Seed Quality Enhancement in Stevia (Stevia rebaudiana Bertoni.)
}

\author{
Aishwarya Yadavannavar ${ }^{1 *}$, V. P. Singh ${ }^{2}$, Bapurayagouda Patil $^{3}$, \\ Y. C. Vishwanath ${ }^{1}$, A. G. Patil ${ }^{4}$ and M. D. Jameel Jhalegar ${ }^{5}$ \\ ${ }^{1}$ Department of Plantation, Spices, Medicinal and Aromatic Crops, \\ College of Horticulture, Bagalkot, Karnataka, India \\ ${ }^{2}$ Department of Plantation, Spices, Medicinal and Aromatic Crops, \\ College of Horticulture, Bidar, Karnataka, India \\ ${ }^{3}$ Department of Seed Science and Technology, Seed Unit, MHREC, College of Horticulture, \\ Bagalkot, Karnataka, India \\ ${ }^{4}$ Department of Agronomy, College of Horticulture, Bidar, Karnataka, India \\ ${ }^{5}$ Department of Post Harvest Technology, College of Horticulture, Bagalkot, Karnataka, India \\ *Corresponding author
}

\section{A B S T R A C T}

Keywords

Stevia, Seed

treatment,

Germination and

$\mathrm{GA}_{3}$

Article Info

Accepted:

17 January 2021

Available Online:

10 February 2021
Stevia is perennial herb belongs to asteraceae family. It is popularly known as sweet leaf, candy leaf, sweet herb and honey leaf which are used to treat diabetes to bring down glucose levels, enhance insulin secretion and in various pharmaceutical formulations. A laboratory experiment was conducted at University of Horticultural Sciences, Bagalkot during 20192020 to assess the seed quality parameters of stevia by treating the seeds with different treatments. The experiment was laid out in a Completely Randomized Design (CRD) with ten treatments in four replications. The seeds of stevia treated with $\mathrm{GA}_{3}$ at $10 \mathrm{ppm}$ soaked for 12 hours had took minimum days for first seed germination (3.00 days), recorded maximum germination $(62.25 \%)$, root length $(10.30 \mathrm{~mm})$, shoot length $(14.15 \mathrm{~mm})$, seedling vigour index (1522), seedling dry weight $(2.90 \mathrm{mg}$ per 10 seedlings) and field emergence $(47.75 \%)$. The growth regulator $\mathrm{GA}_{3}$ at 10 ppm found to be superior in improvement of seed quality parameters of stevia compared to other treatments. 


\section{Introduction}

Stevia (Stevia rebaudiana Bertoni.) is a natural calorie free bio sweetener; it is indigenous to the Amambay region in the Northeast of Paraguay in South America (Alahmad, 2018). The crop stevia is widely dispersed in the neighbouring parts of Brazilian Highlands, Argentina, Central America, South American Andes and SouthEast Asia. An American member of the genus stevia has chromosome number of $2 \mathrm{n}=22$ and it needs a specific photoperiod of 12 to 16 hours for vegetative growth (Frederico et al., 1996). In India, it can be grown very excellent in states like Maharashtra, Punjab, Chhattisgarh, Karnataka, Madhya Pradesh and Andhra Pradesh. The climatic conditions of these states are very much suitable to get good yield and quality. Stevia rebaudiana, as a non-nutritious natural sweetener has risen as a safe sugar substitute for human health. In addition to the sweetening potential, it has numerous therapeutic advantages, as it has diuretic (Bhutia and Sharangi, 2016), antihypertensive (Chan et al., 1998), antihyperglycemic (Jeppesen et al., 2003), antidiarrheal and immune modulator properties (Chatsudthipong and Muanprasat, 2009). The sweet components of stevia are called steviol glycosides which are found in the stevia leaf, used in an extensive range of food items as a non-calorie sweetener. There are different classes of steviol glycosides of which rebaudioside $(13 \%)$ and stevioside $(3-10 \%)$ are most abundant substances (Tavarini and Angelini, 2013).

Stevia demand in herbal world and as raw drugs is increasing day by day, which leads for large scale cultivation and which warrants for huge demand of seeds and planting materials. Stevia is propagated through vegetative cuttings and supply required quantity of planting materials is quite difficult as requires longer period for propagation.
Whereas, propagation by seeds is problematic, because of low germination, due to very small endosperm, infertile in nature and produce variable percentage of viable seed. The information related to germination and seed quality testing of stevia is very meager. Seeds treatment with growth regulators and other substances may regulate the physiological and biochemical process that may initiates seed germination. Hence, the present study was conducted to study the influence of different seed treatments on seed quality enhancement in stevia (Stevia rebaudiana Bertoni.).

\section{Materials and Methods}

The experiment was conducted to study the influence of different seed treatments on seed quality enhancement in stevia (Stevia rebaudiana Bertoni.) at Seed Unit, University of Horticultural Sciences, Bagalkot during the year 2019-2020. The experiment was laid out in Completely Randomized Design (CRD) with ten treatments in four replications. Freshly harvested seeds of stevia were collected from the farmer's field and black colour, fertile seeds were used for the study.

In the present study, the treatment used are $\mathrm{T}_{1}$ : Control (Untreated), $\mathrm{T}_{2}$ : Water soaking for 24 hours, T 3 : IAA @ 5 ppm for 12 hours, $\mathrm{T}_{4}$ : IAA @ 10 ppm for 12 hours, T5: GA 3 @ 5 ppm for 12 hours, $\mathrm{T}_{6}: \mathrm{GA}_{3} @ 10$ ppm for 12 hours, $\mathrm{T}_{7}$ : Kinetin @ 5 ppm for 12 hours, $\mathrm{T}_{8}$ : Kinetin @ 10 ppm for 12 hours, $\mathrm{T}_{9}$ : Humic acid@5\% for 12 hours, $\mathrm{T}_{10}$ : Cow urine@ $40 \%$ for 24 hours. After completion of soaking period, the treated seeds were separated from solution and dried under partial shade and brought back to original moisture content. The seed germination test was performed using petri plate method (top paper method) as described by ISTA (International Seed Testing Association) rules. The treated seeds were kept on the petri 
plates lined with Whatman No. 1 filter paper moistened with $5 \mathrm{ml}$ of distilled water to ensure sufficient moisture for seed germination. Further they were kept in seed germinator at $25 \pm 2^{\circ} \mathrm{C}$ temperature and $85 \pm 3$ per cent relative humidity. Observations were recorded on $15^{\text {th }}$ day for different seed quality parameters. For statistical analysis software used was WASP (Web Agricultural Statistics Software Package).

\section{Results and Discussion}

The stevia seeds treated with seed treatments were showed significant difference with respect to seed quality parameters. The results obtained for different seed quality parameters are discussed here under.

The seeds treated with $\mathrm{GA}_{3}$ at $10 \mathrm{ppm}$ and soaked for $12 \mathrm{hr}$ took minimum number of days for first seed germination (3.00 days), whereas, treatments like $\mathrm{GA}_{3}$ at 5 ppm soaked for $12 \mathrm{hr}$ (3.00 days), kinetin at $5 \mathrm{ppm}$ soaked for $12 \mathrm{hr}$ (3.00 days), kinetin at $10 \mathrm{ppm}$ soaked for $12 \mathrm{hr}$ (3.00 days), IAA at $5 \mathrm{ppm}$ soaked for $12 \mathrm{hr}$ (3.00 days) and water soaked for $24 \mathrm{hr}$ (3.25 days) also took lesser number of days for seed germination. Maximum number of days to first seed germination was recorded in the treatment with cow urine 40 per cent soaked for $24 \mathrm{hr}$ (5.00 days) and IAA at $10 \mathrm{ppm}$ soaked for $12 \mathrm{hr}$ (5.00 days).

Exposure of $\mathrm{GA}_{3}$ recorded early days to commencement of germination, this might be due to it's instigate action on embryo and tends to cause de nova synthesis of hydrolyzing enzymes mainly amylase and protease. Thus, hydrolyzed food is used for embryo development which results in subsequently initiation of early seed germination due to the flow of endogenous auxin and gibberellins like substances (Gurung et al., 2014). These results are in accordance with Chauhan and Nautiyal
(2007) in jatamansi, Khanna et al. (2013) in ashwagandha and Simlat et al. (2019) in stevia.

Higher seed germination per cent was recorded in seeds treated with $\mathrm{GA}_{3}$ at $10 \mathrm{ppm}$ soaked for $12 \mathrm{hr}(62.25 \%)$ and followed by the treatment $\mathrm{GA}_{3}$ at $5 \mathrm{ppm}$ soaked for $12 \mathrm{hr}$ (57.50\%). However, the cow urine at 40 per cent soaked for $24 \mathrm{hr}$ showed least seed germination per cent $(15.75 \%)$. Growth regulator $\mathrm{GA}_{3}$ shown maximum germination per cent, this may be due to involvement of $\mathrm{GA}_{3}$ in enzyme synthesis, one of them is amylase which participates in the breakdown of starch, lipids and protein which transforms the insoluble starch into soluble sugars in endosperm during the course of germination. Thus, these sugars provide energy to seeds that is needed for germination related physiological and metabolic process. $\mathrm{GA}_{3}$ also boosts elongation of cells, such that radical can push through endosperm of seeds which enhances in germination (Barathkumar, 2019). Similar reports with respect to seed germination are recorded by Enkeshwer et al. (2010) in stevia, Simlat et al. (2019) in stevia and Sapra et al. (2020) in ashwagandha.

Among different seed treatments, root length was found to be higher in the seeds treated with $\mathrm{GA}_{3}$ at $10 \mathrm{ppm}$ soaked for $12 \mathrm{hr}(10.30$ $\mathrm{mm})$, which was on par with kinetin at 10 ppm soaked for $12 \mathrm{hr}(10.10 \mathrm{~mm})$ and followed by $\mathrm{GA}_{3}$ at $5 \mathrm{ppm}$ soaked for $12 \mathrm{hr}$ $(9.50 \mathrm{~mm})$. Minimum root length was noticed in humic acid at 5 per cent soaked for $12 \mathrm{hr}$ $(7.85 \mathrm{~mm})$. During early stage of the seed germination, the exogenous application of growth regulator $\mathrm{GA}_{3}$ induced gluconeogenic enzymes activities and improvement in germination characteristics thus reflected in terms of increase in highest root length (Jain et al., 2017). Contrary reports were observed by Ambika et al. (2019) in henna. 
Significantly, maximum shoot length was recorded in $\mathrm{GA}_{3}$ at $10 \mathrm{ppm}$ soaked for $12 \mathrm{hr}$ $(14.15 \mathrm{~mm})$ and followed by kinetin at 10 ppm soaked for $12 \mathrm{hr}(13.10 \mathrm{~mm})$. While, the lowest shoot length $(9.35 \mathrm{~mm})$ was noted in humic acid at 5 per cent soaked for $12 \mathrm{hr}$. The highest values of shoot length obtained with $\mathrm{GA}_{3}$ might be due to the improved osmotic uptake of the nutrients cause cells to multiply and elongation in the cambium tissue, which initiates the metabolic activities, helps for growth of shoot length and nullifies the growth inhibitors in seeds (Singh et al., 1989). Similar reports were observed by Ambika et al. (2019) in henna.

Seedling vigour index was considerably higher in the treatment $\mathrm{GA}_{3}$ at $10 \mathrm{ppm}$ soaked for $12 \mathrm{hr}(1522)$ and followed by $\mathrm{GA}_{3}$ at 5 ppm soaked for $12 \mathrm{hr}$ (1268), while, IAA at $10 \mathrm{ppm}$ soaked for $12 \mathrm{hr}$ showed least seedling vigour index (286).The seedling vigour index was obtained maximum in seeds subjected with $\mathrm{GA}_{3}$, due to higher metabolic activity, respiration rates, better utilization and movement of metabolites to growth point. Metabolic process such as sugar mobilization, oxidation and protein hydrolysis are induced by enzymatic and hormonal mechanism, leads to germination, elongation in length of root and shoot which in turn increases the seedling vigour index (Patel et al., 2018). Similar results were also confirmed by Ambika et al. (2019) in henna and Sapra et al. (2020) in ashwagandha.

Maximum seedling dry weight was noticed in $\mathrm{GA}_{3}$ at $10 \mathrm{ppm}$ soaked for $12 \mathrm{hr}$ (2.90 mg per 10 seedlings), which was on par with kinetin at $10 \mathrm{ppm}$ soaked for $12 \mathrm{hr}(2.75 \mathrm{mg}$ per 10 seedlings) and followed by the treatment $\mathrm{GA}_{3}$ at $5 \mathrm{ppm}$ soaked for $12 \mathrm{hr}(2.58 \mathrm{mg}$ per 10 seedlings). Cow urine at 40 per cent soaked for $24 \mathrm{hr}$ recorded lowest seedling dry weight (1.03 mg per 10 seedlings).
The exogenous soaking of stevia seeds in $\mathrm{GA}_{3}$ for 12 hours produced maximum dry weight of the seedlings, this might have association with overall growth of seedling. Increased growth of seedlings has resulted into the absorption and redistribution of food material in the seedling. The higher mobilization and accumulation of nutrients has lead to elongation of cell, root and shoot length helps for more fresh weight of seedlings. Thus growth of seedlings is results in increase of seedling dry weight (Thorat et al., 2017). These results are in acceptance with findings of Ambika et al. (2019) in henna and Sapra et al. (2020) in ashwagandha.

Seeds treated with $\mathrm{GA}_{3}$ at $10 \mathrm{ppm}$ soaked for $12 \mathrm{hr}$ showed maximum field emergence per cent $(47.75 \%)$, which was on par with $\mathrm{GA}_{3}$ at 5 ppm soaked for $12 \mathrm{hr}(45.25 \%)$ and followed by the treatment kinetin at $5 \mathrm{ppm}$ soaked for $12 \mathrm{hr}(41.50 \%)$. Whereas, the treatment cow urine at 40 per cent soaked for $24 \mathrm{hr}(10.50 \%)$ recorded minimum field emergence per cent. Field emergence was exhibited highest in $\mathrm{GA}_{3}$, one of the main reason is due to maintenance of hormonal balance and suppressing inhibitors of seeds. $\mathrm{GA}_{3}$ is important for stimulation of embryo growth in turn aids for germination of seeds and also helps for production and secretion of hydrolytic enzymes from aleurone cells. Thus, enzymes moves to endosperm storage reserves that boosts for emergence of seed germination and growth (Shariatmadari et al., 2017).

In conclusion, present study indicates that $\mathrm{GA}_{3}$ play roles in controlling seed germination and seedling growth of Stevia. Stevia seeds treated with $\mathrm{GA}_{3}$ at a concentration of $10 \mathrm{ppm}$ found to be superior in improvement of seed quality parameters (Table 1). 
Table.1 Seed quality parameters as influenced by seed treatments in stevia

\begin{tabular}{|c|c|c|c|c|c|c|c|}
\hline Treatments & $\begin{array}{l}\text { Days to first } \\
\text { seed } \\
\text { germination }\end{array}$ & $\begin{array}{c}\text { Seed } \\
\text { germination } \\
(\%)\end{array}$ & $\begin{array}{c}\text { Root } \\
\text { length } \\
(\mathbf{m m})\end{array}$ & $\begin{array}{c}\text { Shoot } \\
\text { length } \\
(\mathrm{mm})\end{array}$ & $\begin{array}{l}\text { Seedling } \\
\text { vigour } \\
\text { index }\end{array}$ & $\begin{array}{c}\text { Seedling dry } \\
\text { weight (mg per } \\
10 \text { seedlings) }\end{array}$ & $\begin{array}{c}\text { Field } \\
\text { emergence } \\
(\%)\end{array}$ \\
\hline $\mathbf{T}_{1-}$ - Control (untreated) & 4.00 & $39.25(38.79)$ & 8.00 & 9.85 & 700 & 1.33 & $29.50(32.89)$ \\
\hline $\mathrm{T}_{2^{-}}$Water soaking for $24 \mathrm{hr}$ & 3.25 & $44.25(41.70)$ & 8.50 & 11.15 & 869 & 1.83 & $35.25(36.42)$ \\
\hline T3- IAA @ 5 ppm for $12 \mathrm{hr}$ & 3.00 & $47.75(43.71)$ & 8.55 & 11.65 & 965 & 2.00 & $38.25(38.20)$ \\
\hline T4- IAA @ 10 ppm for $12 \mathrm{hr}$ & 5.00 & $16.25(23.75)$ & 7.90 & 9.70 & 286 & 1.13 & $11.75(20.02)$ \\
\hline $\mathrm{T}_{5^{-}} \mathrm{GA}_{3} @ 5 \mathrm{ppm}$ for $12 \mathrm{hr}$ & 3.00 & $57.50(49.32)$ & 9.50 & 12.55 & 1268 & 2.58 & $45.25(42.27)$ \\
\hline $\mathbf{T}_{6^{-}} \mathbf{G A}_{3} @ 10 \mathrm{ppm}$ for $12 \mathrm{hr}$ & 3.00 & $62.25(52.09)$ & 10.30 & 14.15 & 1522 & 2.90 & $47.75(43.71)$ \\
\hline $\mathrm{T}_{7}$ - Kinetin@ 5 ppm for $12 \mathrm{hr}$ & 3.00 & $54.25(47.44)$ & 9.00 & 12.30 & 1156 & 2.20 & $41.50(40.11)$ \\
\hline $\mathrm{T}_{8}$ - Kinetin @ 10 ppm for $12 \mathrm{hr}$ & 3.00 & $51.75(46.00)$ & 10.10 & 13.10 & 1201 & 2.75 & $40.00(39.23)$ \\
\hline $\mathrm{T}_{9}$ - Humic acid @ 5\% for $12 \mathrm{hr}$ & 4.00 & $40.25(39.38)$ & 7.85 & 9.35 & 692 & 1.50 & $24.50(29.66)$ \\
\hline $\mathrm{T}_{10^{-}}$Cow urine @ $40 \%$ for $24 \mathrm{hr}$ & 5.00 & $15.75(23.34)$ & 8.35 & 10.5 & 297 & 1.03 & $10.50(18.88)$ \\
\hline S. Em \pm & 0.08 & $0.86(0.55)$ & 0.13 & 0.17 & 21.00 & 0.05 & $0.74(0.49)$ \\
\hline C.D. at $1 \%$ & 0.31 & $3.36(1.60)$ & 0.49 & 0.65 & 80.00 & 0.18 & $2.88(1.91)$ \\
\hline
\end{tabular}

(Values in the parenthesis are arc sine root transformed values) 


\section{References}

Alahmad, K., 2018, Stevia Rebaudiana Bertoni: description and chemical composition. Int. J. Agric. Innov. Res., 7 (2): 230-232.

Ambika, S., Sujatha, K. and Balakrishnan, K., 2019, Seed priming treatments on seedling quality of henna (Lawsonia inermis L.) seeds. In: III International Symposium on Underutilized Plant Species 1241, August, at Madurai, p. 375-380.

Barathkumar, T. R., 2019, Studies on influence of different seed treatments on dormancy breaking in aonla (Phyllanthus embolic L). J. Pharmacogn. Phytochem., 2: 131-133.

Bhutia, P. H. and Sharangi, A. B., 2016, Stevia: Medicinal miracles and therapeutic magic. Int J. Crop Sci. Tech., 2 (2): 45-59.

Chan, P., Xu, D. Y., Liu, J. C., Chen, Y. J., Tomlinson, B., Huang, W. P. and Cheng, J. T., 1998, The effect of stevioside on blood pressure and plasma catecholamines in spontaneously hypertensive rats. Life Sci., 63 (19): 1679-1684.

Chatsudthipong, V. and Muanprasat, C., 2009, Stevioside and related compounds: Therapeutic benefits beyond sweetness. Pharmacol. Ther., 121 (1): 41-54.

Chauhan, R. S. and Nautiyal, M. C., 2007, Seed germination and seed storage behaviour of Nardostachys jatamansi DC., an endangered medicinal herb of high-altitude Himalaya. Curr. Sci ., 92 (11): 1620-1624.

Enkeshwer, P. R., Tyagi, S. and Sumariya, H. K., 2010, Experimental studies on the effects of certain growth regulators on seed germination of Stevia rebaudiana Bertoni. Biosci., Biotech. Res. Asia, 7 (1): 407- 412.
Frederico, A. P., Ruas, P. M., Marales, M. A. M., Ruas, C. F. and Nakajima, J. N., 1996, Chromosome studies in some stevia Cav. (Composite) species from Southern Brazil. Braz. J. Genet., 19 (4): 605-609.

Gurung, N., Swamy, G. S. K., Sarkar, S. K. and Ubale, N. B., 2014, Effect of chemicals and growth regulators on germination, vigour and growth of passion fruit (Passiflora edulis Sims.). The Bioscan, 9 (1): 155-157.

Jain, S., Sharma, T. R., Lal, N., Rangare, N. R. and Kumar, B., 2017, Effect of $\mathrm{GA}_{3}$ and growing media on seed germination and growth of custard apple (Annonas squamosa L.). Int. J. Chem. Stud., 5 (4): 699-707.

Jeppesen, P. B., Gregersen, S., Rolfsen, S. E. D., Jepsen, M., Colombo, M., Agger, A., Xiao, J., Kruhøffer, M., Ørntoft, T. and Hermansen, K., 2003, Antihyperglycemic and blood pressurereducing effects of stevioside in the diabetic Goto-Kakizaki Rat. Metabolism, 52 (3): 372-378.

Khanna, P. K., Kumar, A., Chandra, R. and Verma, V., 2013, Germination behaviour of seeds of Withania somnifera (L.) Dunal: a high value medicinal plant. Physiol. Mol. Biol. Plants, 19 (3): 449-454.

Patel, M., Tank, R. V., Bhanderi, D. R., Patil, H. M., Patel, V. and Desai, M., 2018, Response of soaking time and chemicals on germination and growth of tamarind (Tamarindus indica L.). Plant Archives, 18 (1): 51-56.

Simlat, M., Skrzypek, E., Warchoł, M., Maciaszek, I. and Ptak, A., 2019, Evaluation on Stevia rebaudiana Bertoni seed germination and seedling development under phytohormones treatment. Sci. Hortic., 257: 1-13.

Sapra, N. C., Kalyanrao, P., Sasidharan, N., Das, A. and Susmitha, P., 2020, Effect 
of mechanical, chemical, growth hormone and biofertilizer treatments on seed quality enhancement in ashwagandha (Withania somnifera Dunal). Med. Aromat. Plants, 9 (3): 1-4. Shariatmadari, M. H., Parsa, M., Nezami, A. and Kafi, M., 2017, Effects of hormonal priming with gibberellic acid on emergence, growth and yield of chickpea under drought stress. Bioscience Research, 14 (1): 3441.

Singh, M. G. N., Singh, L. N. and Singh, B. N., 1989, Effect of gibberellic acid on seed germination in mosambi (Citrus sinensis Osbeck). Haryana J. Hort. Sci.,
18 (1-2): 29-33.

Tavarini, S. and Angelini. L. G., 2013, Stevia rebaudiana Bertoni as a source of bioactive compounds: the effect of harvest time, experimental site and crop age on steviol glycoside content and antioxidant properties. Sci. Food Agric., 93 (9): 2121-2129.

Thorat, B. S., Patil, R. R. and Kamble, A. R., 2017, Effect of growth regulators on germination and vigour of cow pea (Vigna unguiculata L. Walp.) seeds. Int. J. Chem. Stud., 5 (6): 766-769.

\section{How to cite this article:}

Aishwarya Yadavannavar, V. P. Singh, Bapurayagouda Patil, Y. C. Vishwanath, A. G. Patil and Jameel Jhalegar, M. D. 2021. Influence of Different Seed Treatments on Seed Quality Enhancement in Stevia (Stevia rebaudiana Bertoni.). Int.J.Curr.Microbiol.App.Sci. 10(02): 2322-2328. doi: https://doi.org/10.20546/ijcmas.2021.1002.276 